\title{
EGFR NP_005219.2:p.E746_A750del
}

National Cancer Institute

\section{Source}

National Cancer Institute. EGFR NP 005219.2:p.E746 A750del. NCI Thesaurus. Code C98537.

A deletion of five amino acids from the epidermal growth factor receptor protein from the glutamic acid at position 746 through the alanine at position 750 . 